\title{
LEVANTAMENTO DE SEIO MAXILAR UTILIZANDO OSSO AUTÓGENO E OSSO LIOFILIZADO COM PRP
}

Fabiano GALINA, Paulo MÜLLER, Nelson Luis Barbosa REBELLATO, Delson João COSTA, Ricardo PASQUINI FILHO

Levantamento de seio maxilar tem se mostrado uma eficiente alternativa para devolver sitio cirúrgico para posterior reabilitação com implantes. O PRP quando misturado com osso particulado, transforma o material de enxertia em algo mecanicamente mais fácil de manipular, com maior volume e estabilidade. Propriedades osteogênicas sempre foram citadas como vantagens do PRP, porém a literatura atual nos leva a desacreditar em tais propriedades. Paciente procurou a Universidade Federal do Paraná com objetivo de enxertia para posterior distribuição de implantes para confecção de um protocolo superior. Devido a pequena disponibilidade de enxerto autógeno em ramo e mento, a equipe optou para retirada de um pequeno bloco em ramo mandibular e misturar com osso liofilizado. O tratamento foi complementado com a utilização de PRP. Após seis meses, podemos constatar uma excelente imagem radiografia que nos sugerem um ótimo sítio para colocação de implantes. Além do que foi citado anteriormente, a técnica cirúrgica utilizada desde a retirada do sangue do paciente pelo farmacêutico até a obtenção do meio adequado para osseointegração de futuros implantes.

Palavras-chave: Plasma rico em plaquetas; Seio maxilar; Implante dentário 